\section{Challenging beliefs in sports nutrition: are two 'core principles' proving to be myths ripe for busting?}

\author{
Peter Brukner
}

Let's start with a couple of quiz questions. Put your hands up if you have given the following pieces of advice to your patients/ athletes. (1) Thirst is not a good indicator of hydration. You must drink lots of fluids before, during and after exercise. (2) The optimum diet for weight control, general health and athletic performance consists of low fat, high carbohydrate.

Well, both my hands are up, and I suspect I am in good company among sports medicine professionals. For the past 30 years, these have been two of the basic tenets of sports nutrition. Recently, however, both these universally regarded 'truths' have been challenged.

\section{MYTHBUSTERS \#1}

We now know that excessive intake of fluid during endurance events can lead to exercise-associated hyponatraemic encephalopathy (EAHE) or 'water intoxication'. 1 There have been a number of deaths reported from this syndrome. One of the researchers who has been prominent in researching this topic is Professor Tim Noakes from the University of Cape Town. In his recent book 'Waterlogged', Noakes explains how drinking too much water can lead to fluid retention and EAHE in those who also have the syndrome of inappropriate antidiuretic hormone secretion (SIADH).

Endurance athletes have been encouraged for the past three decades to not wait until they were thirsty, but to drink large amounts of water or sports drinks to prevent dehydration and heat illness. Noakes advises that excessive fluid overload is the major danger in endurance exercise, not dehydration and heat stroke, and that the old adage of drink when you are thirsty is actually the correct one.

\section{BUSTING AN EVEN BIGGER MYTH?}

In the 1970s and 1980s, there were two schools of thought regarding the best diet

Olympic Park Sports Medicine Centre, Melbourne, Australia

Correspondence to Dr Peter Brukner, Olympic Park Sports Medicine Centre, Olympic Boulevard, AAMI Park, Melbourne, 3004 Australia; peterbrukner@gmail.com for good health-the low fat theory and the low-carbohydrate theory originally proposed by Banting. ${ }^{3}$ In his excellent book The Fat Delusion ${ }^{4}$ (published as Good Calories, Bad Calories ${ }^{5}$ in the USA), science journalist Gary Taubes explains how the low fat theorists won the political battle in the USA despite what he cites is a lack of solid convincing evidence. It was certainly an easy sell-the concept of fatty foods leading to fatty arteries and fat people. At the same time, evidence was emerging of a possible link between cholesterol and atherosclerosis, so the message that fat was bad was reinforced.

There have always been opponents to the low fat theory and they have recommended diets such as The Atkins, South Beach and others. These have been regarded by the medical profession as 'fad diets' and summarily dismissed. So for 30 years there has been an almost universal agreement on the low fat high carbohydrate diet. And yet, in the past 30 years, there has been a steady increase in western countries of the incidence of obesity and type 2 diabetes.

\section{SOCIETY IS EATING 'LOW FAT' BUT GETTING FATTER}

The fact that the obesity and diabetes levels are increasing, and weight loss seems only temporary if at all on low fat low calorie diets, has caused scientists to re-examine the evidence for a low fat or low carbohydrate diet. Once again, Professor Noakes has been at the forefront of this argument having converted personally from high carbohydrate to low carbohydrate high fat with impressive results. ${ }^{6} \mathrm{He}$ now advocates its use in those with impaired carbohydrate metabolism demonstrated by type 2 diabetes or its precursor 'metabolic syndrome'. Interestingly, now Noakes and others not only advocate low carbohydrate and specifically eliminating bread, grains, pasta, rice and potatoes as well as the popular sugarladen soft drinks and fruit juices, but recommend a high fat intake, arguing that saturated fats are important nutrients and do not cause increased levels of small particle cholesterol and triglycerides. ${ }^{6}$ The advocates of the high fat diet emphasise that fats (and to a lesser extent protein) are satiating. Taubes contrasts this with carbohydrates and says in a podcast "who has ever stopped eating potato chips by saying 'yep, I'm full now".

Noakes and other advocates of the low carbohydrate diet paint the hormone insulin as the real culprit. Insulin is secreted by the pancreas in response to carbohydrate ingestion-not in response to fat or protein. ${ }^{4-6}$ The more carbohydrate is ingested, the more insulin is secreted. After the initial increase in blood glucose after a carbohydrate intake, the subsequent blood glucose drop causes hunger. The high level of insulin in those ingesting large amounts of carbohydrate is thought to lead to insulin resistance, where more and more insulin is required to lower the blood glucose concentration. Insulin may also be responsible for the conversion of excess carbohydrate into triglycerides in the liver and subsequently released into the bloodstream.

The low carbohydrate advocates claim that their diet reduces the levels of insulin and therefore the conversion of carbohydrate into body fat. There may also be other advantages of maintaining low blood insulin (and glucose) concentrations since persistently high insulin concentrations may be linked to accelerated ageing, mental decline $^{7}$ and perhaps even specific cancers. ${ }^{8}$

\section{CAN LOW CARBOHYDRATE HIGH FAT PROVIDE FUEL FOR SPORT?}

As for athletic performance, athletes have long been encouraged to load up with carbohydrates prior to and during endurance exercise because glycogen, the storage form of carbohydrate, was thought to be a more efficient fuel than fat. This has also been challenged of late by scientists who argue that fat provides more calories per gram and also has much larger body stores. ${ }^{9}$ Noakes argues that after a week or two of carbohydrate deprivation, our bodies change from a carbohydrate metabolism to a fat metabolism with health and performance improvements. ${ }^{6}$ It would seem that fat is just as effective a fuel for endurance events. What is unclear is whether a high fat low carbohydrate diet is appropriate for athletes in intermittent high-intensity sports such as football or road cycling.

\section{POLARISED VIEWS}

One of Noakes's favourite sayings is ' $50 \%$ of what we are taught is wrong, the challenge is to work out which 50\%'. While an increasing number of health professionals are questioning the effectiveness of low fat diets, the vast majority of the 
profession and all advisory bodies still defend, in some instances quite vehemently, its use especially in the prevention of cardiovascular disease. In addition, there are concerns about the long-term safety of low carbohydrate diets.

There are undoubtedly strong arguments on both sides, and unfortunately the debate has become somewhat controversial and emotive. There are also many individuals, organisations and industries such as the food, agricultural and pharmaceutical, which have a vested interest in maintaining the status quo. ${ }^{10}$ What is urgently needed is a totally objective scientific review of the existing evidence, and support to obtain any further evidence required to answer the question which surely is the most important single question in medicine at the moment. It is essential that this information must be independent of the commercial influences that benefit from the continuation of the status quo.

We have spectacularly failed to prevent the increase in obesity and type 2 diabetes with disastrous health and economic consequences. We need to determine once and for all whether our profession's universal recommendation of a low fat high carbohydrate diet is the correct one.

BJSM will pursue this topic over the coming months in an attempt to shed light on the issue.

\section{Competing interests None.}

Provenance and peer review Not commissioned; internally peer reviewed.

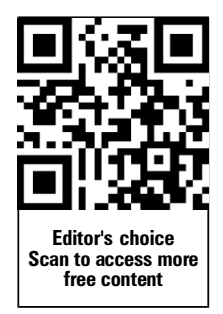

To cite Brukner P. Br J Sports Med 2013;47:663-664.

Accepted 20 March 2013

Published Online First 20 April 2013

Br J Sports Med 2013;47:663-664.

doi:10.1136/bjsports-2013-092440

\section{REFERENCES}

1 Noakes TD, Speedy DB. Case proven: exercise associated hyponatraemia is due to overdrinking. So why did it take 20 years before the original evidence was accepted? Br J Sports Med 2006:40:567-7.

2 Noakes TD. Waterlogged: the serious problem of overhydration in endurance sports. Champaign, IL: Human Kinetics, 2012.

3 Banting W. Letter on corpulence, addressed to the public. 4th edn. Harrison, London: Republished Cosimo Publishing, 2005 New York (originally published in 1864).

4 Taubes G. The diet delusion. London: Vermillion, 2008

5 Taubes G. Good calories, bad calories. New York: Alfred A. Knopf, 2007.

6 Noakes T. Tim Noakes on carbohydrates. http://www. health24.com/Diet-and-nutrition/Nutrition-basics/ Tim-Noakes-on-carbohydrates-20120721 (accessed 11 Mar 2013)

7 Roberts RO, Roberts LA, Geda YE, et al. Relative intake of macronutrients impacts risk of mild cognitive impairment or dementia. J Alzheimers Dis 2012:32:329-39.

8 Klement RJ, Kammerer U. Is there a role for carbohydrate restriction in the treatment and prevention of cancer? Nutr Metab 2011;8:75.

9 Volek JS, Phinney SD. The art and science of low carbohydrate performance. Miami, Florida: Beyond Obesity LLC, 2012

10 Moss M. Salt, sugar and fat. Random House, New York, 2013 